\title{
Organo-mineral additives based on oil and gas complex waste to building materials
}

\section{Органоминеральные добавки к строительным материалам на основе отходов газовой и нефтяной промышленности}

\author{
T.A. Litvinova, \\ Kuban State Technological University, \\ Krasnodar, Russia
}

\author{
Канд. техн. наук, доцент Т.А. Литвинова, \\ Кубанский государственный \\ технологический университет, \\ 2. Краснодар, Россия
}

Key words: buildings; organo-mineral additives; oilcontaminated waste; spent sorbents; waste utilization; ecological safety; secondary resources; expanded clay

\author{
Ключевые слова: здания; \\ органоминеральные добавки; \\ нефтесодержащие отходы; отработанные \\ сорбенты; утилизация отходов; \\ экологическая безопасность; вторичные \\ ресурсы; керамзит
}

\begin{abstract}
The use of waste and products of their utilization as secondary raw materials is promising and rational way for their disposal. The addition of waste to mixtures provides either highquality products or improvement some of the physical and mechanical characteristics. Organo-mineral additives are produced by oil-contaminated waste and spent sorbents utilization meet environmental safety requirements and are suitable for use as an additive in building materials, for example, expanded clay and asphalt mixtures. The aim of the paper is to develop technology for producing organo-mineral additives that is aimed at the elimination of environmental pollution with wastes, their involvement into resource circulation and ensures rational nature management with reducing the consumption of reagents and receiving high quality ecologically safety products. It is established the minimum necessary quantity of quicklime (calcium oxide reagent) required to transfer viscous sludge in bulk and obtain organo-mineral additives. In order to achieve the most important technical parameters of building materials in particular expanded clay - a bulk density and strength, it is used various additives. Application of the complex additives can increase the swelling clay factor up to 3 times and get the required strength of concrete block with less energy consumption, which significantly reduces the cost of the products. It is carried out the research to develop formulations of puddle clay with organo-mineral additives and choose burning conditions for preparing expanded clay. It's established the optimal temperatures and a thermal presintering for producing products that meet the requirements of the standards, with minimal energy consumption. The impact of the percentage of organo-mineral additive on the coefficient of clay swelling is determined. In the process of burning poor swelling clay with using organo-mineral additive at temperature $1050{ }^{\circ} \mathrm{C}$ constructive quality factor is increased by $70-97 \%$ in comparison with the expanded clay obtained from raw materials without additives. Proposed technology for production of expanded clay with organo-mineral additives allows getting high-quality environmentally friendly products and disposing in its composition oil and gasing complex waste, involving them into resource management, and satisfies best available techniques due to encouraging re-use of waste.
\end{abstract}

Аннотация. Использование отходов и продуктов их переработки в качестве вторичного сырья является перспективным и рациональным способом их утилизации. Добавление отходов в смеси обеспечивает и высокое качество продуктов, и улучшение некоторых физико-механических характеристик. Органоминеральные добавки, получаемые при обезвреживании отработанных сорбентов и нефтесодержащих отходов, отвечают требованиям экологической безопасности и пригодны для использования в качестве добавки в строительные материалы, например, керамзит и асфальтобетонные смеси. Целью работы является разработка технологии получения органоминеральных добавок, которая направлена на ликвидацию загрязнения окружающей среды отходами, их вовлечение в ресурсооборот и обеспечение рационального природопользования через уменьшение потребления реагентов и получение высококачественной экологически безопасной продукции. Установлено минимальное необходимое количество негашеной извести (реагента оксида кальция), требуемое для перевода вязкотекучего шлама в сыпучее и получения органоминеральных добавок. Для достижения наиболее важных технических характеристик строительных материалов, в частности, керамзита - насыпной плотности и прочности, применяют Литвинова Т.А. Органоминеральные добавки к строительным материалам на основе отходов газовой и нефтяной промышленности // Инженерно-строительный журнал. 2016. № 7(67). С. 13-21. 
различные добавки. Органические добавки улучшают вспучивание глины и снижают насыпную плотность керамзита. Кремнеземсодержащие добавки помогают увеличить прочность готового продукта. Применение комплексных добавок способствует увеличению коэффрициента вспучивания глины до $3 x$ раз и получению требуемой прочности бетонного блока с меньшим потреблением энергии, что значительно снижает себестоимость продукции. Было проведено исследование по разработке составов глинистого теста с органоминеральными добавками и выбору режима обжига для получения керамзита. Были установлены оптимальные температуры и режим предварительной термоподготовки для производства продукта, отвечающего требованиям стандартов, с минимальным потреблением энергии. Определено влияние процентного содержания органоминеральной добавки на коэффициент вспучивания глины. В процессе обжига слабовспучивающейся глины с использованием органоминеральной добавки при температуре $1050{ }^{\circ} \mathrm{C}$ коэффрициент конструктивного качества увеличивается на 70-97\% по сравнению с керамзитом, полученным из сырья без добавок. Таким образом, предлагаемая технология для производства керамзита с органоминеральными добавками позволяет получить высококачественные экологически безопасные продукты и утилизировать в своем составе отходы нефтегазового комплекса, вовлекая их в ресурсооборот, и отвечает требованиям наилучших доступных технологий, стимулируя повторное использование отходов.

\section{Introduction}

The current situation in the field of formation, accumulation and disposal of oil and gas complex waste leads to dangerous contamination of all components of the environment - surface water and groundwater, vegetative ground cover, air, as well as unsustainable use of natural resources, significant economic damage and poses a real threat to health current and future generations of the country. At the enterprises of the oil and gas industry oily waste are generated during the construction of oil and gas wells, commercial exploitation, transportation and processing of oil and gas, treatment of waste water containing oil products and cleaning of tanks and other equipment. The accumulation of large masses of waste is due to objectively existing level of technology for the processing of raw materials and lack of its complex use.

For the oil industry it is characterized formation of oil-contaminated liquid and solid waste - waste water and sludge. Most of the refinery waste is oil sludge generated in the wastewater treatment process; scales and deposits on equipments. Output of oil sludge is up to $10 \mathrm{~kg}$ per 1 ton of crude oil processed [1]. Among the solid waste of oil refining let us note the spent adsorbents used for wastewater treatment and spent catalysts used in the catalytic oil processing. Considering the gas industry, there is spent adsorbent formed by the dehydration of natural gas. Every year during the extraction of fuel and energy minerals it's generated about 2000 million tons of oil sludge, including in Krasnodar Territory - to 12000 tons [2].

The use of oil-containing waste as secondary raw materials is one of the most efficient methods for their treatment and disposal. Oil sludge has been used in road construction, building materials, fuel industry, oil and gas industry. Adding sludge in mixtures allows obtaining high-quality products that comply with regulatory requirements, to improve some of the physical and mechanical characteristics similar products. Areas of oil sludge use are chosen both by technological, technical and sanitary requirements for products, as well as on performance standards for raw materials. Suitability oil waste as technogenic raw materials is determined during their complex analysis.

Thus, it is topical and essential the development of effective methods of oil and gas complex waste disposal and the best available techniques of their utilization for the elimination of air, water, soil pollution by waste of hazard classes II to III and environmental remediation. Along with this it is important resource-using waste and products of their disposal as complex additives in building materials, involving at the same time waste into resource management.

The possibility of using oil sludge in the production of building materials are determined by the type of the products (brick, concrete block, aggregates) and the role of waste in the process (burn-out additive or softener).

Oil-contaminated waste is widely used as the organic binder in the manufacture of waterproofing materials. Using the oil waste can not only reduce the consumption of bitumen or oil, but also obtain materials with high physical and mechanical properties [4-7].

It is worth noticing an insulating material [8] that can be used in the disposal of toxic industrial waste of hazard classes III to IV, including municipal solid waste. The material contains clay (1060 mass.\%), sediment of staked lime or sludge of chemical water purification in quality of used lime 
waste material (15-40 mass.\%), bottom, floating oil-slime or soil polluted with mineral oils in quality of oilslime (25-50 mass.\%).

It is used oil waste solidification techniques that allow to get products in the form of blocks for it use as structural elements in the construction and waterproofing of landfills for the disposal of waste. Method of detoxifying petroleum-containing wastes includes adding 10-\% aqueous emulsion of waterproofing liquid and resultant mixture is solidified by mixing with cement. The quantity of oil waste in the composition ranges from 20.8 to 41.6 mass.\% [9].

In research papers [10-14] it is suggested the use of oil sludge for production of expanded clay. According to the mineral composition of oil sludge waste are similar to the components of the raw mixture, and according to the fractional composition of the organic part they are similar to expansion admixture.

In order to improve the quality of expanded clay it is commonly used various additives. Organic additives can improve distension clay, resulting in a reduction in the bulk density of expanded clay. Silicacontaining supplements help to increase the strength of the finished product due to the saturation of silicium ions and increase the proportion of vitreous component. It is used organo-mineral and alkaline additives to reduce the burning temperature. Powdering the pellets with refractory powders surface, in particular limestone, ground quartz sand, gypsum causes blistering expansion slot. Application of the complex additives can increase the swelling clay factor of up to 3 times and get the required strength of concrete block with less energy consumption which significantly reduces the cost of the product.

At the Department of oil and gas technology it is developed technologies of oil-contaminated waste disposal by reagent method with introducing quicklime and adsorbing additives based on industrial waste, including oil and gas industry (waste siliceous adsorbents: silica gels, ODM-2F, diatomite, C-sorbents, the products of pyrolysis of used tires, rice husk) [15-23]. The composition of waste utilization products is suitable for use as complex additives in building materials, for example, in the production of expanded clay and asphalt concrete [24-29]. Patented technologies take into account the requirements for BAT [30, 31]. One of the criteria for inclusion to the BAT is encouraging re-use of waste. Application of BAT in the oil and gas industry is a comprehensive solution to the problem of waste management, including the transition to energy-efficient, resource-saving technologies to the improvement of the environment and citizens' health. Using BAT in the field of waste management will eliminate the environmental pollution by waste [32-34].

The composition of oil utilization products by reagent method includes calcium oxide, silicon oxide and conversion products, calcium hydroxide, encapsulated hydrocarbons from oil-sludge and organic compounds from the spent silicious sorbents. Consequently, those products are organo-mineral additives and in fact are complex additives for increasing the coefficient of clay swelling, reduction the bulk density and maintaining granule strength. The introduction of neutralized oil sludge makes it possible to mix clay mass without contamination of working area, eliminating the release of hydrocarbons and other harmful substances from waste. Organic components stimulate porization of expanded clay and intensify processes occurring during the clay swelling including the transition clay into pyroplastic state. By reducing the bulk density of expanded clay it is important to ensure an optionally strength because increasing the pore size causes a sharp decline in the strength of the pellets due to the reduction of wall thickness and then enhance stress concentrations. Not only volume and pore size affect on the strength of porous materials. The structure and composition of the solid phase component of the vitreous play a great role. The strength of the vitreous increases by the saturation of aluminum and silicium ions. Therefore, silica-containing additives, including the siliceous spent sorbents, help to increase the strength of the finished product.

Following the research the objectives of this study are to develop technology for producing organomineral additives for the elimination of environmental pollution with wastes, to involve wastes into resource circulation and to ensure rational nature management with reducing the consumption of reagents and to receive high quality ecologically safety products.

\section{Methods}

Method of obtaining organo-mineral additive to building materials consists in mixing oilcontaminated sludge with quicklime, preliminarily milled to a finely dispersed condition, and exhausted silica gel, which represents the gas industry waste product at the stage of natural gas drying, with the following introduction of water. As for exhausted silica gel it contains more than 90 mass \% silicon oxide, 2.4 mass \% coke deposits, 3.6 mass \% organic components and the remaining metal oxide [35-36], and 
it's used as the hydraulic additive in manufacture of waterproof concretes on the basis of calsealpuzzolane binding agent [37-40].

The necessary quantity of water for slaking is determined stoichiometrically including water, present in the oil-contaminated sludge, and wateradsorption of exhausted silica gel. The obtained organo-mineral additive is exposed until the process of calciumsilicate structure formation is finished. First, the quantity of oil components in the oil-contaminated sludge is determined, which is then used to calculate the necessary quantity of quicklime (1).

$$
y=(0.023 x-0.001) \cdot m,
$$

where $\mathrm{y}$ - necessary quantity of quicklime, $\mathrm{kg}$;

$x$ - quantity of oil components in the oil-contaminated sludge, mass. \%;

$\mathrm{m}$ - quantity of oil-contaminated sludge, $\mathrm{kg}$;

0.023 - empirically determined coefficient;

0.001 - empirically determined coefficient.

The obtained data are used to calculate the necessary quantity of exhausted silica gel (2).

$$
\mathrm{z}=1.1 \cdot \mathrm{y},
$$

where $\mathrm{z}$ - necessary quantity of exhausted silica gel, $\mathrm{kg}$;

1.1 - empirically determined coefficient, taking into account the quantity of silicon oxide in exhausted silica gel.

Before mixing powdered quicklime it's treated with waterproofing additive in the form of a solid technical fat, heated to a temperature of $28-40^{\circ} \mathrm{C}$, taken in an amount calculated by equation 3 :

$$
\mathrm{n}=0.05 \cdot \mathrm{y},
$$

where $\mathrm{n}$ - necessary quantity of waterproofing additive, $\mathrm{kg}$;

0.05 - empirically determined coefficient.

The obtained by this method organo-mineral additive meets ecological safety requirements and is suitable for use as a complex additive in construction materials.

\section{Results and Discussion}

For the rational disposal of oil-contaminated waste and production effective organo-mineral additives to building materials it's important to determine necessary quantity of quicklime taking into account oil components in waste. The dependence of oil-sludge neutralization efficiency from quantity of quicklime (Fig. 1) is obtained by experimental research of the effectiveness of oily waste neutralization with different quantity of organic components.

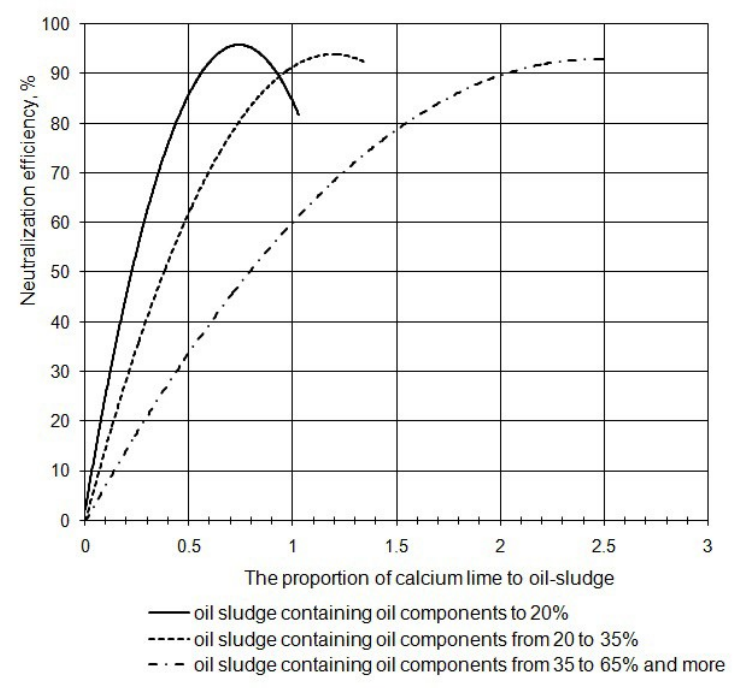

Figure 1. The dependence of oil-sludge neutralization efficiency from quantity of quicklime

Litvinova T.A. Organo-mineral additives based on oil and gas complex waste to building materials. 
It is established the minimum necessary quantity of quicklime (calcium oxide reagent) required to transfer viscous sludge in bulk and obtain organo-mineral additives. To achieve neutralization efficiency of $85-95 \%$ the proportion of calcium lime to oil-sludge varies widely the average from 0.4 to 1.7 and higher. Thus further increase quicklime leads to decrease in the efficiency of neutralization, which is associated with an excess of the reagent.

With a minimum quantity basic reagent (quicklime) environmental safety of organo-mineral additives is achieved by increasing the quantity of silica component in neutralizing composition exhausted silica gel, the main part of which is silicon oxide.

So, considering the composition of organo-mineral additive it is a complex additive, for example, for increasing the coefficient of clay swelling, reduction the bulk density and maintaining granule strength.

Formulation of puddle clay for preparing expanded clay with additives deals with the selection the optimum percentage of additive in the raw mix to achieve the requirements of standards for the products. It is carried out the research to develop formulations of puddle clay with organo-mineral additives and choose burning conditions for preparing expanded clay.

Method of preparing expanded clay involves mixing clay raw material, an additive and water, granulation of the obtained mixture, drying and burning. Mixing is carried out in two steps. At the first step clay raw material is mixed with the additive (1-5 mass \%). At the second step water is added in an amount sufficient for obtaining a mixture with water content of 18-20\%. In accordance with the composition of the raw materials it's characterized by quantity of silicon oxide $67.84 \%$ and quantity of organic components $0.40 \%$, so it refers to moderately ductile raw materials. With adding organo-mineral additive in quantity from 1 to 5 mass. \% the clay composition will be included in the regulated Russian technical specifications TU 21-0284739-12-90 value.

Selecting the mode of burning raw granules is to establish the optimal temperatures and a thermal pre-sintering for producing products that meet the requirements of the standards, with minimal energy consumption. Test results of obtained expanded clay samples showed that optimum temperature conditions are rapid and gradual thermal treatment at temperatures of $200,300,400{ }^{\circ} \mathrm{C}$ with the addition of $1-3 \%$ OMD in the burning temperature range from 1050 to $1110^{\circ} \mathrm{C}$.

The impact of the percentage of organo-mineral additive on the coefficient of clay swelling is expressed by the following relationship (Fig. 2).

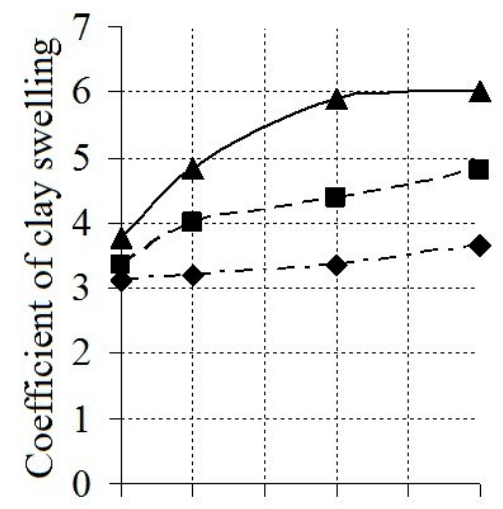

$\begin{array}{llllll}0 & 1 & 2 & 3 & 4 & 5\end{array}$

Organo-mineral additive, $\%$

a)

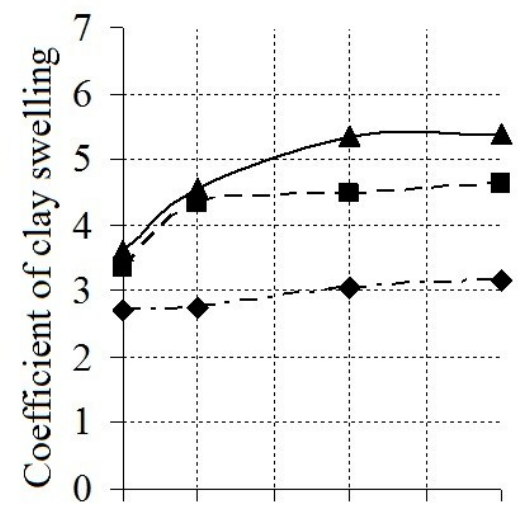

$\begin{array}{llllll}0 & 1 & 2 & 3 & 4 & 5\end{array}$

Organo-mineral additive, $\%$

b)

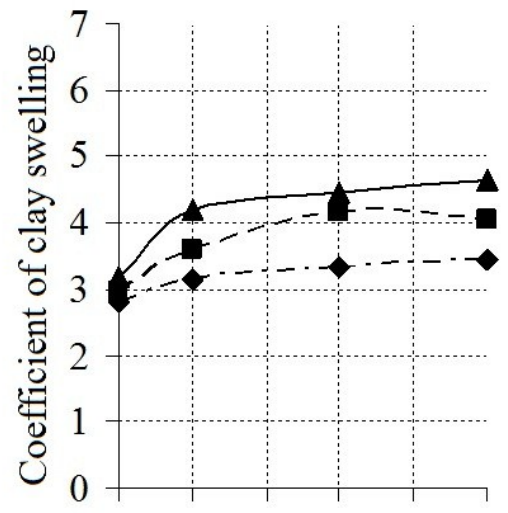

$\begin{array}{llllll}0 & 1 & 2 & 3 & 4 & 5\end{array}$

Organo-mineral additive, $\%$

c)

$-\cdots$ burning temterature $1050^{\circ} \mathrm{C}--$-burning temterature $1080^{\circ} \mathrm{C} \longrightarrow$ burning temterature $1110^{\circ} \mathrm{C}$

\section{Figure 2. The impact of the percentage of organo-mineral additive on the coefficient of clay swelling at various burning temperatures and rapid thermal treatment at $200{ }^{\circ} \mathrm{C}(\mathrm{a}), 300^{\circ} \mathrm{C}(\mathrm{b}), 400^{\circ} \mathrm{C}$ (c)}

In the range of raw materials burning from 1050 to $1110^{\circ} \mathrm{C}$ adding organo-mineral additive in quantity 1 mass. \% increases the coefficient of swelling from 3 to $40 \%$ in comparison with pure raw materials. Adding organo-mineral additive in quantity 3 mass. \% increases the coefficient of swelling from 5 to $45 \%$ and in quantity 5 mass. $\%$ - from 12 to $50 \%$. However, the use $5 \%$ of organo-mineral additive limits the narrow swelling range in $30^{\circ} \mathrm{C}$ and surface glazing at a lower temperature $1110^{\circ} \mathrm{C}$ due to the increase the organic components in the clay composition.

Литвинова Т.А. Органоминеральные добавки к строительным материалам на основе отходов газовой и нефтяной промышленности // Инженерно-строительный журнал. 2016. № 7(67). С. 13-21. 
Thus, in the process of burning poor swelling clay with using organo-mineral additive at temperature $1050{ }^{\circ} \mathrm{C}$ constructive quality factor is increased by $70-97 \%$ in comparison with the expanded clay obtained from raw materials without additives. Therefore, developed method is energysaving, environmentally friendly and technologically appropriate technology of expanded clay production.

\section{Conclusions}

1. The research results can be used in the oil and gas industry to utilize the accumulated and annually produced at the enterprises technogenic waste for minimization environmental pollution, while reducing air, water and soil pollution by waste of hazard classes II to III; as well as in the building industry, reducing the consumption of natural resources and energy.

2. The developed technology for production of expanded clay with organo-mineral additive provides preparing high-quality environmentally friendly expanded clay and disposed in its composition oily waste and meets BAT requirements.

3. The use of complex additives OMD increases coefficient of clay swelling up to 3 times and obtaining the required strength of expanded clay with lower energy consumption, which significantly reduces the cost of the product due to the use raw materials of poor quality.

4. It is established the optimal temperatures and a thermal pre-sintering for producing products that meet the requirements of the standards, with minimal energy consumption.

5. The impact of the percentage of organo-mineral additive on the coefficient of clay swelling is determined. In the process of burning poor swelling clay with using organo-mineral additive at temperature $1050{ }^{\circ} \mathrm{C}$ constructive quality factor is increased by $70-97 \%$ in comparison with the expanded clay obtained from raw materials without additives.

\section{References}

1. Sbornik udel'nyh pokazatelej obrazovanija othodov proizvodstva i potreblenija [Summary of specific formation indicators of production and consumption waste]. Moscow, 1999. 65 p. (rus)

2. Gosudarstvennyj doklad o sostojanii i ob ohrane okruzhajushhej sredy Rossijskoj Federacii [State report on the environment and environmental protection of the Russian Federation] [Online]. URL: http://www.ecogosdoklad.ru/ (date of reference: 03.09.2016). (rus)

3. Shperber R.E., Shperber E.R., Shperber F.R., Shperber I.R., et al. Sposob prigotovlenija gidroizoljacionnogo krovel'nogo materiala [Method of preparing hydroinsulating roofing material]. Patent Russia no. 2175661, 2001. (rus)

4. Shperber R.E., Shperber E.R., Shperber F.R., Shperber I.R., et al Gidroizoljacionnyj krovel'nyj material [Hydroinsulating roofing material]. Patent Russia no. 2176653, 2001. (rus)

5. Shperber E.R., Bokovikova T.N., Shperber D.R Gidroizoljacionnyj krovel'nyj material [Hydroinsulating roofing material]. Chemistry and Technology of Fuels and Oils. 2012 No. 6. Pp. 40-42. (rus)

6. Malashonok B.I., Shevchuk I.N., Malashonok N.G., Sedykh Ju.l. Kompozicija dlja krovel'nyh i gidroizoljacionnyh mastik i listovyh rulonnyh krovel'nyh gidroizoljacionnyh materialov [Composition for roofing and hydroinsulating mastic and sheet roll roofing and hydroinsulating materials]. Patent Russia no. 2058348, 1996. (rus)

7. Khalilov V.Sh., Gil'manov K.G., Akhmadeeva Z.M., Gera L.N., et al. Izolirujushhij material [Insulating material] Patent Russia no. 2271882, 2006. (rus)

8. Gil'manov K.G., Khalilov I.V. Izolirujushhij material im-1 [Insulating material im-1]. Regional Environmental Issues. 2011. No. 3. Pp. 172-177. (rus)

9. Vlasicheva L.G., Tikhomirova M.F. Sposob obezvrezhivanija neftesoderzhashhih othodov [Method of detoxifying petroleum-containing wastes]. Patent Russia no. 2126773,1999 . (rus)

10. Pozdnyshev G.N., Ehl'konjuk A.A., Kazakov V.A.,

\section{Литература}

1. Сборник удельных показателей образования отходов производства и потребления. Москва, 1999. 65 с.

2. Государственный доклад о состоянии и об охране окружающей среды Российской Федерации [Электронный ресурc]. URL: http://www.ecogosdoklad.ru/ (дата обращения: 03.09.2016).

3. Пат. 2175661 Российская Федерация, МПК C08L95/00, E04D5/00. Способ приготовления гидроизоляционного кровельного материала / Шпербер P.Е., Шпербер Е.P., Шпербер Ф.Р., Шпербер И.Р. и др.; заявитель и патентообладатель СНТМП «ЭЗИП». - № 99123602/03; заявл. 10.11.99; опубл. 10.11.01.

4. Пат. 2176653 Российская Федерация, МПК C08L95/00 E04D5/00. Гидроизоляционный кровельный материал. Шпербер P.Е., Шпербер Е.P., Шпербер Ф.Р., Шпербер И.Р. и др.; заявитель и патентообладатель СНТМП «ЭЗИП». - № 9912365/03; заявл. 10.11.99; опубл. 10.12.01.

5. Шпербер Е.Р., Боковикова Т.Н., Шпербер Д.Р. Гидроизоляционый кровельный материал // Нефтепереработка и нефтехимия. научно-технические достижения и передовой опыт. 2012. № 6. С. 40-42

6. Пат. 2058348 Российская Федерация, МПК C08L95/00, C08K7/00, C08K11/00. Композиция для кровельных и гидроизоляционных мастик и листовых рулонных кровельных и гидроизоляционных материалов / Малашонок Б.И., Шевчук И.Н., Малашонок Н.Г., Седых Ю.И.; заявитель и патентообладатель ТОО фрирма «Тайм». - № 92007502/04; заявл. 20.11.92; опубл. 20.04.96.

7. Пат. 2271882 Российская Федерация, МПК В09В1/00. Изолирующий материал / Халилов В.Ш., Гильманов Х.Г., Ахмадеева 3.М., Гера Л.Н., Шайбекова Э.Б.; заявитель и патентообладатель Халилов В.Ш., Гильманов Х.Г. - № 2004129228/03; заявл. 04.10.04; опубл. 20.03.06, Бюл. № 8

8. Гильманов Х.Г., Халилов И.В. Изолирующий материал им-1 // Проблемы региональной экологии. 2011. № 3 C. $172-177$

9. Пат. 2126773 Российская Федерация, МПК C02F11/00 В09B3/00. Способ обезвреживания нефтесодержащих

Litvinova T.A. Organo-mineral additives based on oil and gas complex waste to building materials. Magazine of Civil Engineering. 2016. No. 7. Pp. 13-21. doi: 10.5862/MCE.67.2 
Chernikov A.K. Syr'evaja smes' dlja proizvodstva legkogo zapolnitelja [Raw mixture for light filler production]. Patent Russia no. 2049750, 1995. (rus)

11. Filippova O.P., Makarov V.M., Jamanina N.S., Timrot S.D. Syr'evaja smes' dlja proizvodstva legkogo zapolnitelja [Raw mix for manufacturing light aggregate]. Patent Russia no. 2287499, 2006. (rus)

12. Safronov V.S., Chernyshova N.E., Dubrovina V.A., Tsirulina E.K. Syr'evaja smes' dlja proizvodstva legkogo zapolnitelja [Raw material mixture for light-weight filler production]. Patent Russia no. 2055030, 1996. (rus)

13. Safronov V.S., Chernyshova N.E., Tsirulina E.K., Dubrovina V.A., Izmaylov V.D. Razrabotka osnov kompleksnogo ispol'zovanija othodov neftepererabotki i neftehimii v proizvodstve keramzita [Development of bases of complex use of refinery and petrochemical wastes in the production of expanded clay]. Himicheskaja Promyshlennost'. 1994. No. 7. P. 20. (rus)

14. Shperber R.E., Shperber E.R., Shperber F.R. Sposob poluchenija keramzita [Method of manufacturing claydite]. Patent Russia no. 2112758, 1998. (rus)

15. Shperber E.R., Bokovikova T.N., Shperber D.R. Ispol'zovanie nefteshlamov vodoochistnyh sooruzhenij v kachestvevspuchivajushhej dobavki pri poluchenii keramzita [Oil sludge of waste water treatment facilities application as a blowing agent in haydite production]. Oil and Gas Technologies. 2012. No. 6(83). Pp. 3-7. (rus)

16. Gil'manov Kh.G., Khalilov V.Sh., Kamalov A.K., Fatkhutdinov Z.A., et al. Sposob prigotovlenija vspuchivajushhej dobavki [Method of preparation of expansion admixture]. Patent Russia no. 2218314, 2003. (rus)

17. Kosulina T.P., Solntseva T.A. Sposob obezvrezhivanija neftesoderzhashhih shlamov [Method of decontaminating oily mud]. Patent Russia no. 2395466, 2010. (rus)

18. Litvinova T.A., Kosulina T.P. Sposob poluchenija organomineral'noj dobavki $\mathrm{k}$ stroitel'nym materialam [Method of obtaining organo-mineral additive to building materials]. Patent Russia no. 2548441, 2015. (rus)

19. Tsokur O.S., Litvinova T.A., Kosulina T.P. Primenenie nailuchshih dostupnyh tehnologij dlja utilizacii promyshlennyh othodov [The use of best available techniques for recycling industrial waste]. IV Mezhdunarodnaja nauchnaja jekologicheskaja konferencija Problemy rekul'tivacii othodov byta, promyshlennogo i sel'skohozjajstvennogo proizvodstva. [Proceedings IV International scientific ecological conference Problems of reclamation of domestic solid waste, industrial and agricultural production waste]. Krasnodar: KGAU, 2015. Pp. 728-732. (rus)

20. Kosulina T.P., Tsokur O.S., Litvinova T.A. [Ispol'zovanie obezvrezhivajushhej kompozicii dlja utilizacii nefteshlamov i otrabotannogo sorbenta ODM-2F]. Using of decontamination composition for utilization of oil-slimes and exhausted sorbent ODM-2F. Environmental bulletin of scientific center Black Sea Economic Cooperation. 2013. No. 3. Pp. 77-84. (rus)

21. Litvinova T.A., Vinnikova T.V., Kosulina T.P. Reagentnyj sposob obezvrezhivanija nefteshlamov [Reagent method of oil-Ssimes neutralization]. Ecology and Industry of Russia. 2009. No. 10. 12 p. (rus)

22. Litvinova T.A., Kosulina T.P. Recycling of oil-and-gas complex solid wastes. International Journal of Applied and Fundamental Research. 2009. No. 2. P. 61.

23. Litvinova T.A., Kosulina T.P., Shadrina D.S., Chirkova S.S. Recycling of oil-slimes by chemical method. European Journal of Natural History. 2010. No. 1. P. 77.

24. Litvinova T.A., Tsokur O.S., Zubenko Yu.Yu., Kosulina T.P. Reshenie problemy utilizacii neftesoderzhashhih othodov $s$ vovlecheniem in $v$ resursooborot [Solution of the problem of oil-containing waste utilization with their involvement in resource cycle]. Modern problems of отходов / Власичева Л.Г., Тихомирова М.Ф.; заявитель и патентообладатель АО «Уральский научноисследовательский центр по архитектуре и строительству». - № 96115630/25; заявл. 26.07.96; опубл. 27.02.99.

10. Пат. 2049750 Российская Федерация, МПК С04B14/12. Сырьевая смесь для производства легкого заполнителя / Позднышев Г.Н., Эльконюк А.А., Казаков В.А., Черников А.К.; заявитель и патентообладатель Позднышев Г.Н., Эльконюк А.А., Казаков В.А. Черников А.К. - № 5030555/33; заявл. 04.03.92; опубл. 10.12 .95 .

11. Пат. 2287499 Российская Федерация, МПК С04В14/12. Сырьевая смесь для производства легкого заполнителя / Филиппова О.П., Макаров В.М., Яманина Н.С., Тимрот С.Д.; заявитель и патентообладатель Ярославский государственный технический университет . - № 2005106007/03; заявл. 03.03.05; опубл. 20.11.06, Бюл. № 32

12. Пат. 2055030 Российская Федерация, МПК С04B14/12 Сырьевая смесь для производства легкого заполнителя / Сафронов В.С., Чернышова Н.Е., Дубровина В.А., Цирулина Е.К.; заявитель и патентообладатель Самарский государственный технический университет - № 5026366/33; заявл. 23.12.91; опубл. 27.02.96.

13. Сафонов В.С., Чернышова Н.Е., Цирулина Е.К., Дубровина В.А., Измайлов В.Д. Разработка основ комплексного использования отходов нефтепереработки и нестехимии в производстве керамзита // Химическая промышленность. 1994. № 7 C. 20.

14. Пат. 2112758 Российская Федерация, МПК С04В14/12 Способ получения керамзита / Шпербер Р.Е., Шпербер Е.Р., Шпербер Ф.Р.; заявитель и патентообладатель СНТМП «ЭЗИП». - № 96120970/03; заявл. 15.10.96 опубл. 10.06.98.

15. Шпербер Е.Р., Боковикова Т.Н., Шпербер Д.Р Использование нефттешламов водоочистных сооружений в качествевспучивающей добавки при получении керамзита // Технологии нефрти и газа. 2012. № $6(83)$. С. 3-7.

16. Пат. 2218314 Российская Федерация, МПК С04В14/00 Способ приготовления вспучивающей добавки / Гильманов Х.Г., Халилов В.Ш., Камалов А.К., Фатхутдинов З.А., Уфимцев В.Г., Нигматуллин И.Р. Ольков П.Л.; заявитель и патентообладатель ООО «ЭКВУС». - № 2000112305/03; заявл. 16.05.00; опубл. 10.12.03.

17. Пат. 2395466 Российская Федерация, МПК C02F11/14 В09B3/00. Способ обезвреживания нефтесодержащих шламов / Косулина Т.П., Солнцева Т.А.; заявитель и патентообладатель ГОУВПО «КубГТУ». № 2008147569/15; заявл. 02.12.08; опубл. 27.07.10, Бюл. № 21.

18. Пат. 2548441 Российская Федерация, МПК C02F11/14 C04B18/00. Способ получения органоминеральной добавки к строительным материалам / Литвинова Т.А. Косулина Т.П.; заявитель и патентообладатель ГОУВПО «КубГТУ». - № 2013155369/05; заявл. 12.12.13; опубл. 20.04.15, Бюл. № 11.

19. Цокур О.С., Литвинова Т.А., Косулина Т.П. Применение наилучших доступных технологий для утилизации промышленных отходов // IV Международная научная экологическая конференция Проблемы рекультивации отходов быта, промышленного и сельскохозяйственного производства. Краснодар: Кубанский государственный аграрный университет, 2015. С. 728-732.

20. Косулина Т.П., Цокур О.С., Литвинова Т.А Использование обезвреживающей композиции для утилизации несттешламов и отработанного сорбента ОДМ-2Ф // Экологический вестник научных центров

Литвинова Т.А. Органоминеральные добавки к строительным материалам на основе отходов газовой и нефтяной промышленности // Инженерно-строительный журнал. 2016. № 7(67). С. 13-21. 
science and education. 2012. No. 6 [Online]. URL: http://www.science-education.ru/ru/article/view?id=7707 (date of reference: 02.09.2016). (rus)

25. Litvinova T.A., Pavlenko P.P., Kosulina T.P. Ispol'zovanie organomineral'nyh dobavok na osnove othodov neftegazovogo kompleksa $v$ proizvodstve keramzita [Application of organic-mineral additives on the basis of oil and gas industry's waste products in manufacture of expanded clay aggregate]. Ecology and Industry of Russia. 2011. No. 3. C. 20-22. (rus)

26. Solntseva T.A., Kosulina T.P. Sposob poluchenija keramzita [Method of preparing expanded clay]. Patent Russia no. 2397963, 2010.

27. Solntseva T.A., Kosulina T.P. Linija po obezvrezhivaniju neftesoderzhashhego shlama [Line for the disposal of oily sludge]. Patent Russia no. 82208, 2009

28. Kosulina T.P., Litvinova T.A., Shadrina D.S., Chirkova S.S Linija po proizvodstvu organomineral'noj dobavki [Production line of organo-mineral additive]. Patent Russia no. 93791, 2010. (rus)

29. Kosulina T.P., Kononenko E.A., Tsokur O.S. Sposob prigotovlenija asfal'tobetonnoj smesi [Method to prepare asphalt-concrete mixture]. Patent Russia no. 2515652 2014. (rus)

30. Kosulina T.P., Kononenko E.A., Tsokur O.S Sposob prigotovlenija asfal'tobetonnoj smesi [Road concrete mix making method]. Patent Russia no. 2520256, 2014. (rus)

31. Directive 2010/75/EC on industrial emissions (integrated pollution prevention and control)

32. GOST R 54097-2010. Resursosberezhenie. Nailuchshie dostupnye tehnologii. Metodologija identifikacii [Russian Standart GOST R 54097-2010. Resource-saving. Best Available Techniques. Identification methodology]. $13 \mathrm{p}$.

33. Litvinova T.A., Tsokur O.S., Kosulina T.P. O vybore nailuchshih dostupnyh tehnologij utilizacii othodov neftegazovoj otrasli [On the choice of the best available techniques for oil and gas industry waste utilization] Modern problems of science and education. 2012. No. 6 . P. 53. (rus)

34. Litvinova T.A. Innovacionnyj podhod na osnove principov NDT k razrabotke utilizacii neftesoderzhashhih othodov [Innovative approach based on the principles of BAT to develop technology of oil-contaminated waste utilization] Scientific Journal of KubSAU. 2016. No. 115(01). Pp. $1-$ 13. [Electronic resource]. System requirements AdobeAcrobatReader. http://ej.kubagro.ru/2016/01/pdf/19.pdf (date of application: 02.09.2016). (rus)

35. Kosulina T.P., Al'varis Ya.A., Solntseva T.A. Issledovanie tverdyh othodov neftegazovogo kompleksa i ispol'zovanie in V kachestve VMR 1. Sostav zagrjaznenij, obrazujushhihsja na silikagele pri podgotovke prirodnogo gaza k transportu [Research into oil and gas complex solid wastes and their usage as a secondary raw material 1. The composition and structure of contaminants forming on the surface of silica gel in natural gas preparation for transport]. Zashhita okruzhajushhej sredy $v$ neftegazovom komplekse. 2008. No. 1. Pp. 16-20. (rus)

36. Kosulina T.P., Solntseva T.A., Levashov A.S., Al'varis Ya.A. Issledovanie tverdyh othodov neftegazovogo kompleksa i ispol'zovanie ih $\mathrm{v}$ kachestve VMR. 3.* O strukture zagrjaznenij i klasse opasnosti otrabotannogo silikagelja - othoda gazopererabotki [Research into oil and gas complex solid wastes and their usage as a secondary raw material. 3. About contaminants structure and danger class of exhausted silica gel - the waste of gas processing industry]. Zashhita okruzhajushhej sredy $v$ neftegazovom komplekse. 2009. No. 2. Pp. 33-38. (rus)

37. Chernykh V.F., Kosulina T.P., Al'varis Ya.A., Solntseva T.A., Ermakov E.I., Shestakova E.V. Sposob poluchenija gipsocementno-puccolanovogo vjazhushhego [Method for production of gypsum cement-pozzolana binder]. Patent
Черноморского экономического сотрудничества. 2013. № 3. C 77-84.

21. Литвинова Т.А., Винникова Т.В., Косулина Т.П. Реагентный способ обезвреживания нефтешламов // Экология и промышленность России. 2009. № 10. C. 12.

22. Litvinova T.A, Kosulina T.P. Recycling of oil-and-gas complex solid wastes // International Journal of Applied and Fundamental Research. 2009. № 2. P. 61

23. Litvinova T.A, Kosulina T.P., Shadrina D.S., Chirkova S.S Recycling of oil-slimes by chemical method // European Journal of Natural History. 2010. № 1. Р. 77.

24. Литвинова Т.А., Цокур О.С., Зубенко Ю.Ю., Косулина Т.П. Решение проблемы утилизации нефтесодержащих отходов с вовлечением их в ресурсооборот // Современные проблемы науки и образования. 2012. № 6. [Электронный ресурc]. URL: http://www.science-education.ru/ru/article/view?id=7707 (дата обращения: 02.09.2016)

25. Литвинова Т.А., Павленко П.П., Косулина Т.П. Использование органоминеральных добавок на основе отходов нефтегазового комплекса в производстве керамзита // Экология и промышленность России. 2011. № 3. С. 20-22.

26. Пат. 2397963 Российская Федерация, МПК С04В14/12 C04B20/06. Способ получения керамзита / Солнцева Т.А., Косулина Т.П.; заявитель и патентообладатель ГОУВПО «КубГТУ». - № 2008147568/03; заявл. 02.12.08; опубл. 27.08.10, Бюл. № 24

27. Пат. 82208 Российская Федерация, МПК C02F1/40. Линия по обезвреживанию нефтесодержащего шлама Солнцева Т.А., Косулина Т.П.; заявитель и патентообладатель ГОУВПО «КубГТУ». - № 2008152572/22; заявл. 29.12.08; опубл. 20.04.09, Бюл. № 11 .

28. Пат. 93791 Российская Федерация, МПК C02F1/40. Линия по производству органоминеральной добавки / Косулина Т.П., Литвинова Т.А., Шадрина Д.С., Чиркова С.С.; заявитель и патентообладатель ГОУВПО «КубГТУ». - № 2010101175/22; заявл. 15.01.10; опубл. 10.05.10, Бюл. № 13 .

29. Пат. 2515652 Российская Федерация, МПК С04В26/26 C04B40/00, C04B111/27. Способ приготовления асфральтобетонной смеси / Косулина Т.П., Кононенко Е.А., Цокур О.С.; заявитель и патентообладатель ГОУВПО «КубГТУ». - № 2012147416/03; заявл. 07.11.12; опубл. 20.05.14, Бюл. № 14.

30. Пат. 2520256 Российская Федерация, МПК С04В26/26 C04B40/00, C04B111/20. Способ приготовления асфальтобетонной смеси / Косулина Т.П., Кононенко Е.А., Цокур О.С.; заявитель и патентообладатель ГОУВПО «КубГТУ». - № 2012147431/03; заявл. 07.11.12; опубл. 20.06.14, Бюл. № 17.

31. Directive 2010/75/EC on industrial emissions (integrated pollution prevention and control).

32. ГОСТ P 54097-2010 Ресурсосбережение. Наилучшие доступные технологии. Методология идентификации. $13 \mathrm{c}$.

33. Litvinova T.A., Tsokur O.S., Kosulina T.P. О выборе наилучших доступных технологий утилизации отходов нефтегазовой отрасли // Современные проблемы науки и образования. 2012. № 6. С. 53.

34. Литвинова Т.А. Инновационный подход на основе принципов НДТ к разработке утилизации нефтесодержащих отходов // Научный журнал КубГАУ. 2016. № 115(01). С. 1-13. [Электронный ресурс]. Систем. требования: AdobeAcrobatReader. URL: http://ej.kubagro.ru/2016/01/pdf/19.pdf (дата обращения: 02.09.2016)

35. Косулина Т.П., Альварис Я.А., Солнцева Т.А. Исследование твердых отходов нефтегазового комплекса и использование их в качестве ВMP 1.

Litvinova T.A. Organo-mineral additives based on oil and gas complex waste to building materials Magazine of Civil Engineering. 2016. No. 7. Pp. 13-21. doi: 10.5862/MCE.67.2 
Russia no. 2368580, 2009. (rus)

38. Chernykh V.F., Kosulina T.P., Al'varis Ya.A., Solntseva T.A., Ermakov E.I., Shestakova E.V. Linija po proizvodstvu gipsocementno-puccolanovogo vjazhushhego [Line for production of gypsum cement-pozzolana binder]. Patent Russia no. 74102, 2008

39. Al'varis Ya.A., Chernykh V.F., Solntseva T.A., Kosulina T.P. Issledovanie tverdyh othodov neftegazovogo kompleksa $i$ ispol'zovanie in $v$ kachestve VMR. 2.* Utilizacija otrabotannogo silikagelja $s$ polucheniem jekologicheski bezopasnyh stroitel'nyh materialov [Research into oil and gas complex solid wastes and their usage as a secondary raw material. 2. Recycling of exhausted silica gel with production of ecologically safe construction materials]. Zashhita okruzhajushhej sredy v neftegazovom komplekse. 2009. No. 1. Pp. 31-37. (rus)

40. Kosulina T.P., Litvinova T.A., Chernykh V.F. Ispol'zovanie otrabotannogo silikagelja pri proizvodstve betonov [Application of solid waste products of oil-and-gas complex as hydraulic additive in manufacture of safe concretes]. Ecology and industry of Russia. 2010. No. 2. Pp. 30-32. (rus)

Tatiana Litvinova,

+78612557895; soleado_STA@mail.ru
Состав загрязнений, образующихся на силикагеле при подготовке природного газа к транспорту // Защита окружающей среды в нефтегазовом комплексе. 2008. № 1. С. 16-20.

36. Косулина Т.П., Солнцева Т.А., Левашов А.С., Альварис Я.А. Исследование твердых отходов нефтегазового комплекса и использование их в качестве ВМР. 3. ${ }^{*}$ O структуре загрязнений и классе опасности отработанного силикагеля - отхода газопереработки // Защита окружающей среды в нефтегазовом комплексе. 2009. № 2. С. 33-38.

37. Пат. 2368580 Российская Федерация, МПК С04В11/30. Способ получения гипсоцементно-пуццоланового вяжущего / Черных В.Ф., Косулина Т.П., Альварис Я.А., Солнцева Т.А., Ермаков Е.И., Шестакова Е.В.; заявитель и патентообладатель ГОУВПО «КубГТУ». № 2007141113/03; заявл. 06.11.2007; опубл. 20.05.2009, Бюл. № 27.

38. Пат. 74102 Российмская Федерация, МПК В28С5/38. Линия по производству гипсоцементно-пуццоланового вяжущего / Черных В.Ф., Косулина Т.П., Альварис Я.А., Солнцева Т.А., Ермаков Е.И., Шестакова Е.В.; заявитель и патентообладатель ГОУВПО «КубГТУ». № 2008107463/22; заявл. 26.02.08; опубл. 20.06.08, Бюл. № 17.

39. Альварис Я.А., Черных В.Ф., Солнцева Т.А., Косулина Т.П. Исследование твердых отходов нефтегазового комплекса и использование их в качестве ВMP. 2.* Утилизация отработанного силикагеля с получением экологически безопасных строительных материалов // Защита окружающей среды в нефртегазовом комплексе. 2009. № 1. С. 31-37.

40. Косулина Т.П., Литвинова Т.А., Черных В.Ф. Использование отработанного силикагеля при производстве бетонов // Экология и промышленность в России. 2010. № 3. С. 30-32.

Татьяна Андреевна Литвинова, +78612557895;

эл. почта: soleado_STA@mail.ru

(c) Litvinova T.A., 2016

Литвинова Т.А. Органоминеральные добавки к строительным материалам на основе отходов газовой и нефтяной промышленности // Инженерно-строительный журнал. 2016. № 7(67). С. 13-21. 